\title{
PERJALANAN MANDIRI SISWA SMP PASCAPENERAPAN SISTEM ZONASI PENERIMAAN SISWA BARU DI KOTA YOGYAKARTA
}

\author{
Fajar Zawa Tri Mulya \\ Magister Perencanaan Wilayah dan Kota \\ Universitas Gadjah Mada \\ Jln. Grafika No. 2, Yogyakarta \\ fajar.zawa.t@ugm.ac.id
}

\author{
Yori Herwangi \\ Magister Perencanaan Wilayah dan Kota \\ Universitas Gadjah Mada \\ Jln. Grafika No. 2, Yogyakarta \\ yherwangi@ugm.ac.id
}

\begin{abstract}
One of the goals of implementing school zoning system is to bring school closer to home, thus providing a further impact on children's mobility to school more independent. Children's independent mobility measured from trips to and from school without accompanied by adults. Deductive-quantitative research approaches are used to describe CIM changes and influencing factors. A total of 628 students before and after implementation of school zoning system from 5 schools in the Yogyakarta City become respondents. The results showed that independent trips to and from school increased by $8.6 \%$ and $5.1 \%$. The children's independent mobility types almost similar between two groups. The most significant facilitating factor are parental permit and parent's time to go home from work be significant barrier. While distance and crossing arterial/railroad give less barrier. Boys and peer support are facilitator variables. Then, directly go home and long routes became significant barrier for students after implementation of school zoning system.
\end{abstract}

Keywords: children independent mobility; urban junior high school students; school zoning system.

\begin{abstract}
Abstrak
Salah satu tujuan penerapan sistem zonasi sekolah adalah mendekatkan lingkungan sekolah dengan lingkungan keluarga, sehingga dapat memberi dampak lanjut perjalanan anak ke sekolah lebih mandiri. Perjalanan mandiri anak sekolah diukur dari perjalanan berangkat dan perjalanan pulang sekolah yang dilakukan sendiri tanpa diantar oleh orang dewasa. Penelitian ini menggunakan pendekatan deduktif-kuantitatif untuk mendeskripsikan perubahan perjalanan mandiri anak dan faktor-faktor yang memengaruhinya. Sejumlah 628 siswa sebelum dan setelah penerapan sistem zonasi dari 5 SMP di Kota Yogyakarta menjadi responden. Hasil penelitian ini menunjukkan bahwa perjalanan mandiri berangkat dan pulang sekolah meningkat sebesar 8,6\% dan 5,1\%. Tipe perjalanan mandiri anak relatif sama di antara kedua kelompok. Variabel yang signifikan mendorong adalah izin orang tua, tetapi waktu orang tua pulang kerja bersamaan pulang sekolah menghambat secara signifikan. Jarak rumah dan penyeberangan jalan arteri atau rel kereta api juga berpengaruh menghambat. Jenis kelamin laki-laki dan dukungan teman menjadi variabel pendorong. Tujuan langsung ke rumah dan rute yang memutar jauh menghambat secara signifikan bagi siswa setelah penerapan zonasi.
\end{abstract}

Kata-kata kunci: perjalanan mandiri anak; siswa smp perkotaan; sistem zonasi sekolah.

\section{PENDAHULUAN}

Jarak sekolah yang jauh dan waktu tempuh yang lama sering kali membuat para pelajar perlu menggunakan kendaraan bermotor pribadi untuk berangkat dan pulang sekolah (Setiawan, 2011). Sedangkan kondisi kota yang tidak ramah anak dan kota dengan layanan transportasi yang belum tertata dengan baik, membuat anak diantar-jemput orang tua (Putri et al., 2019). 
Mulai tahun 2018 Pemerintah Kota Yogyakarta menerapkan sistem zonasi pada penerimaan siswa baru. Sistem ini memungkinkan anak bersekolah di sekitar lingkungan rumah, sehingga memungkinkan anak pergi ke sekolah secara mandiri.

Kelompok anak usia SMP menarik untuk diamati, karena telah memiliki aktivitas yang lebih tinggi dan mandiri, namun belum diperbolehkan menggunakan kendaraan bermotor. Istilah yang digunakan adalah golongan pilihan moda terbatas atau captive riders (Aprilia, 2014). Perbandingan perjalanan mandiri anak dilakukan untuk mengetahui apakah ada peningkatan kemandirian anak serta faktor yang memengaruhinya.

Perjalanan Mandiri Anak dapat diartikan sebagai kebebasan anak untuk bepergian di lingkungan sekitar rumah atau kota mereka tanpa pengawasan orang dewasa (Marzi dan Reimers, 2018). Para peneliti ini menjelaskan perjalanan mandiri anak dengan berbagai sudut pandang, seperti: (1) kemandirian dalam perjalanan menuju suatu tempat, seperti rumah te-man, toko lokal, taman bermain; (2) spesifikasi perjalanan mandiri ke sekolah; (3) kemandi-rian dalam berjalan kaki, bersepeda, naik kendaraan umum; dan (4) kemandirian dalam bermain di lingkungan sekitar rumah.

Penelitian spesifikasi perjalanan mandiri ke sekolah sebelumnya (Hidayati, 2011) membagi tipe perjalanan mandiri anak menjadi 4 tipe. Keempat tipe tersebut adalah pulangpergi diantar (termasuk nebeng), berangkat diantar-pulang sendiri, berangkat sendiri-pulang dijemput, pulang-pergi sendiri. Moda transportasi yang digunakan diasumsikan berkaitan langsung perjalanan mandiri anak disajikan dalam Tabel 1.

Tabel 1 Moda Transportasi Mandiri Siswa SMP

\begin{tabular}{lll}
\hline \multirow{2}{*}{ No. } & \multicolumn{2}{c}{ Moda Transportasi } \\
\cline { 2 - 3 } & Mandiri & \multicolumn{1}{c}{ Tidak Mandiri } \\
\hline 1 & Jalan kaki & Sepeda motor \\
2 & Sepeda & Mobil \\
3 & Bus & Mobil antar-jemput sekolah \\
4 & Ojek online & \\
\hline
\end{tabular}

Faktor yang diidentifikasi didapat dari masing-masing arah perjalanan pulang atau arah perjalanan pergi (Buliung et al., 2017). Penelitian sebelumnya banyak menghubungkan langsung perilaku atau pola perjalanan dengan bentuk kota. Namun belum menunjukkan hasil yang signifikan, sehingga perlu dimasukkan faktor kondisi sosio-ekonomi keluarga, persepsi, dan perilaku orang tua (McMillan, 2005).

Faktor pola perjalanan diidentifikasi dari variabel jarak, durasi, dan tujuan perjalanan. Umumnya jarak menjadi hambatan anak untuk berjalan kaki dan bersepeda, sehingga untuk jarak tertentu perlu menggunakan kendaraan bermotor (Hidayati, 2011; Nugraha dan Dewi, 2018; Putri et al., 2019). Mitra dan Buliung (2015) mengidentifikasi batas maksimal 3,2 km anak mau berjalan kaki ke sekolah. Jarak ini 2 kali jarak standar jangkauan SMP di perkotaan yang disarankan, yaitu 1,6 km (Aprilia, 2014). Sedangkan durasi perjalanan yang disarankan adalah paling lama 20 menit, atau mendekati nilai rata-rata hasil penelitian sebelumnya (Setiawan, 2011; Aprilia, 2014; Ahern et al, 2017). Selain itu, tujuan perjalanan sepulang sekolah memengaruhi pilihan moda siswa SMA (Schlossber et al., 2006; Akbar, 2019). 
Faktor bentuk kota paling sering dikaitkan dengan perilaku perjalanan (McMilan, 2005). Karakter rute berkaitan langsung dengan aspek bentuk kota. Rute perjalanan yang melewati atau menyeberangi jalan arteri atau rel kereta api menghambat anak untuk berjalan mandiri (Mitra dan Buliung, 2015; Putri et al., 2019).

Rasio rute langsung (route directness) diukur dari panjang rute terhadap jarak lurus ke rumah. Mitra dan Buliung (2015) menemukan bahwa semakin besar rasio atau rute semakin jauh, semakin besar kemungkinan untuk anak diantar kendaraan bermotor ke sekolah.

Keberadaan trotoar mendukung anak untuk berjalan kaki (Carver et al., 2014). Studi yang dilakukan oleh Carver et al. (2014) juga menemukan bahwa anak di perkotaan lebih mandiri daripada anak di pedesaan.

Untuk jarak jauh, pilihan moda akan bertambah jika lokasi rumah terjangkau akses kendaraan umum (Mitra dan Buliung, 2015). Sedangkan keterjangkauan akses yang disarankan adalah $400 \mathrm{~m}$ (BSN, 2004).

Faktor sosioekonomi yang banyak ditemukan berpengaruh adalah jenis kelamin, yang mana anak laki-laki umumnya lebih mandiri daripada anak perempuan (McMilan, 2005). Selain itu, banyaknya jumlah anak bersekolah meningkatkan penggunaan kendaraan bermotor dalam keluarga (McMillan, 2005; Mitra dan Buliung, 2015).

Keluarga dengan pendapatan tinggi cenderung memilih sekolah tertentu yang mengakibatkan lokasi jauh dari rumah (Van Geoverden dan de Boer, 2013). Pendapatan yang tinggi juga memungkinkan keluarga memiliki kendaraan bermotor, dan hal ini menghambat anak untuk berjalan kaki, bersepeda, maupun menggunakan kendaraan umum.

Persepsi anak dapat ditambahkan untuk mengetahui lebih dalam bagaimana anak memandang lingkungannya. Hidayati (2011) menemukan bahwa lebih dari 50\% anak yang pulang dan pergi diantar, berpandangan negatif terhadap kendaraan umum. Keamanan lingkungan dari tindak kejahatan (Race et al., 2017) maupun lalu lintas yang ramai menghambat anak bepergian sendiri (Carver et al., 2014). Sedangkan dukungan teman untuk bepergian bersama mengurangi ketergantungan anak kepada orang dewasa (Carver et al., 2014) dan memotivasi perjalanan ke sekolah (Race et al., 2017).

Keputusan perjalanan anak sangat bergantung pada orang tua (McMilan, 2005; Ahern et al., 2017). Aktivitas orang tua, seperti tipe pekerjaan yang fleksibel dan waktu berangkat dan pulang kerja yang bersamaan dengan waktu sekolah, cenderung memengaruhi orang tua untuk mengantar-jemput anak ke sekolah (Mitra dan Buliung, 2015). Carver et al. (2014) menemukan bahwa izin orang tua pada anak untuk bermain di sekitar rumah memengaruhi perjalan mandiri anak.

\section{METODE PENELITIAN}

Pada studi ini digunakan pendekatan deduktif-kuantitatif untuk mendeskripsikan perubahan perjalanan mandiri anak. Data primer diambil dari kuesioner yang diisi langsung oleh responden, yang disebar di 5 SMP Negeri di Kota Yogyakarta. Sekolah yang dipilih berada 
di daerah pusat perkotaan dan di pinggiran kota serta melihat sebaran prestasi nilai ujian akhir, yaitu tertinggi, tengah, dan terendah. Lebih dari 700 kuesioner disebar dan dihasilkan data responden melebihi jumlah kebutuhan minimal pada tingkat kepercayaan 95\%. Jumlah responden secara proporsional ditampilkan pada Tabel 2.

Tabel 2 Jumlah Responden yang Diperoleh

\begin{tabular}{clcccc}
\hline $\begin{array}{c}\text { Peringkat Rata-Rata } \\
\text { UN 2018 }\end{array}$ & Sekolah & $\begin{array}{c}\text { Siswa } \\
\text { TA 2017 }\end{array}$ & Responden & $\begin{array}{c}\text { Siswa } \\
\text { TA 2018 }\end{array}$ & Responden \\
\hline 1 & SMPN 5 & 320 & 102 & 311 & 102 \\
4 & SMPN 9 & 204 & 59 & 199 & 60 \\
10 & SMPN 7 & 204 & 60 & 203 & 61 \\
14 & SMPN 3 & 204 & 57 & 207 & 58 \\
16 & SMPN 13 & 103 & 36 & 103 & 33 \\
\hline & Total & 1035 & 314 & 1023 & 314 \\
\hline
\end{tabular}

Kuesioner berisi data terkait variabel yang diduga berpengaruh, seperti yang terdapat dalam tinjauan pustaka. Khusus untuk mendapatkan titik lokasi rumah yang akurat, responden diminta membagikan titik lokasi rumah dengan menggunakan tautan aplikasi Google Maps ke dalam aplikasi Google Form yang telah disediakan. Deskripsi variabel tersebut disajikan pada Tabel 3.

Tabel 3 Variabel yang Dapat Diduga Berpengaruh pada Perjalanan Mandiri Anak

\begin{tabular}{|c|c|c|}
\hline Variabel & Keterangan & Pengukuran \\
\hline Moda (Y) & Jenis kendaraan yang digunakan & $\begin{array}{l}1=\text { Moda perjalanan mandiri } \\
0=\text { Moda perjalanan tidak mandiri }\end{array}$ \\
\hline \multicolumn{3}{|l|}{ Faktor Pola Perjalanan } \\
\hline $\begin{array}{l}\text { Radius jarak tempat } \\
\text { tinggal (X1) }\end{array}$ & $\begin{array}{l}\text { Jarak lurus dari tempat tinggal ke } \\
\text { sekolah }\end{array}$ & 1-6: jarak kelipatan 1,6 km \\
\hline $\begin{array}{l}\text { Durasi lama waktu } \\
\text { perjalanan }(\mathrm{X} 2)\end{array}$ & $\begin{array}{l}\text { Rata-rata waktu tempuh } \\
\text { melakukan perjalanan }\end{array}$ & $\begin{array}{l}1 \text { (cepat): durasi } \leq 10 \text { menit } \\
2 \text { (sedang): } 10 \text { menit }<\text { durasi } \leq 20 \text { menit } \\
3 \text { (lama): } 20 \text { menit }<\text { durasi }\end{array}$ \\
\hline Tujuan pulang (X3) & $\begin{array}{l}\text { Tujuan perjalanan sepulang } \\
\text { sekolah }\end{array}$ & $\begin{array}{l}1=\text { Langsung ke rumah } \\
0=\text { Selain rumah (misal: les, rumah teman, dll.) }\end{array}$ \\
\hline \multicolumn{3}{|l|}{ Faktor Bentuk Kota } \\
\hline $\begin{array}{l}\text { Karakter lokasi tempat } \\
\text { tinggal }(\mathrm{X} 4)\end{array}$ & $\begin{array}{l}\text { Keberadaan lokasi tempat tinggal } \\
\text { siswa }\end{array}$ & $\begin{array}{l}3=\text { Kota Yoyakarta (perkotaan) } \\
2=\text { Kawasan Perkotaan Yogyakarta (pinggiran) } \\
1=\text { Desa di luar KPY (pedesaan) }\end{array}$ \\
\hline $\begin{array}{l}\text { Keberadaan pedestrian } \\
\text { (X5) }\end{array}$ & $\begin{array}{l}\text { Keberadaan pedestrian sepanjang } \\
\text { rute jalan arteri }\end{array}$ & $\begin{array}{l}1=\text { Pedestrian terus ada } \\
0=\text { Pedestrian tidak terus ada/terputus }\end{array}$ \\
\hline $\begin{array}{l}\text { Penyebrangan jalan } \\
\text { arteri/rel kereta (X6) }\end{array}$ & $\begin{array}{l}\text { Ada/tidaknya rute yang } \\
\text { menyeberangi jalan arteri/rel } \\
\text { kereta pada rute yang dilewati }\end{array}$ & $\begin{array}{l}1=\text { Rute menyebrang jalan arteri/rel kereta } \\
0=\text { Rute tidak menyebrang jalan arteri/rel kereta }\end{array}$ \\
\hline $\begin{array}{l}\text { Rasio rute langsung } \\
(\mathrm{X} 7)\end{array}$ & $\begin{array}{l}\text { Rasio/perbandingan panjang rute } \\
\text { perjalanan terdekat siswa ke } \\
\text { sekolah dengan jarak lurus dari } \\
\text { rumah ke sekolah }\end{array}$ & $\begin{array}{l}1=\text { Rasio } 1-1,5 \text { (rute lebih panjang hingga } 50 \% \\
\text { dari radius) } \\
2=\text { Rasio diatas } 1,5 \text { (rute lebih panjang di atas } \\
\\
50 \% \text { dari radius) }\end{array}$ \\
\hline $\begin{array}{l}\text { Akses kendaraan umum } \\
(\mathrm{X} 8)\end{array}$ & $\begin{array}{l}\text { Jarak rumah ke tempat berhenti } \\
\text { kendaraan umum }\end{array}$ & $\begin{array}{l}1=\text { Jarak } \leq 400 \mathrm{~m} \\
0=\text { Jarak }>400 \mathrm{~m}\end{array}$ \\
\hline
\end{tabular}


Tabel 3 Variabel yang Dapat Diduga Berpengaruh pada Perjalanan Mandiri Anak (Lanjutan)

\begin{tabular}{|c|c|c|}
\hline Variabel & Keterangan & Pengukuran \\
\hline \multicolumn{3}{|l|}{ Faktor Sosio-ekonomi } \\
\hline Jenis kelamin (X9) & Laki-laki/perempuan & 1 = laki-laki; $0=$ perempuan \\
\hline $\begin{array}{l}\text { Anggota keluarga } \\
\text { bersekolah (X10) }\end{array}$ & $\begin{array}{l}\text { Jumlah anggota keluarga yang } \\
\text { masih bersekolah }\end{array}$ & $\begin{array}{l}1=1 \text { anak bersekolah } \\
2=2 \text { anak bersekolah } \\
3=\text { lebih dari } 2 \text { anak bersekolah }\end{array}$ \\
\hline Pendapatan (X11) & Gabungan orang tua & 1-4: nominal kelipatan Rp2.000.000,-- \\
\hline $\begin{array}{l}\text { Kepemilikan kendaraan } \\
(\mathrm{X} 12-\mathrm{X} 14)\end{array}$ & $\begin{array}{l}\text { Kendaraan yang dimiliki (Mobil, } \\
\text { Sepeda Motor, Sepeda) }\end{array}$ & $\begin{array}{l}1=\text { Memiliki } \\
0=\text { Tidak memiliki }\end{array}$ \\
\hline \multicolumn{3}{|l|}{ Faktor Persepsi Anak } \\
\hline $\begin{array}{l}\text { Pandangan kendaraan } \\
\text { umum (X15) }\end{array}$ & $\begin{array}{l}\text { Skala Likert pandangan pada } \\
\text { kendaraan umum }\end{array}$ & $\begin{array}{l}\text { 1-5: makin besar, responden cenderung } \\
\text { berpandangan positif terhadap kendaraan umum }\end{array}$ \\
\hline $\begin{array}{l}\text { Persepsi keamanan lalu } \\
\text { lintas (X16) }\end{array}$ & $\begin{array}{l}\text { Skala Likert pandangan siswa } \\
\text { terhadap kondisi lalu lintas } \\
\text { selama perjalan ke sekolah }\end{array}$ & $\begin{array}{l}\text { 1-5: makin besar, responden merasa lalu lintas } \\
\text { aman }\end{array}$ \\
\hline $\begin{array}{l}\text { Persepsi keamanan } \\
\text { lingkungan (X17) }\end{array}$ & $\begin{array}{l}\text { Skala Likert pandangan siswa } \\
\text { terhadap keamanan lingkungan, } \\
\text { orang asing dan tindak kejahatan } \\
\text { selama perjalanan }\end{array}$ & $\begin{array}{l}\text { 1-5: makin besar, responden merasa lingkungan } \\
\text { aman }\end{array}$ \\
\hline $\begin{array}{l}\text { Dukungan teman sebaya } \\
\text { (X18) }\end{array}$ & $\begin{array}{l}\text { Skala Likert pandangan } \\
\text { responden terhadap keberadaan } \\
\text { teman sebaya dalam } \\
\text { memengaruhi perjalanan siswa }\end{array}$ & $\begin{array}{l}\text { 1-5: makin besar, keberadaan teman sebaya } \\
\text { semakin berpengaruh }\end{array}$ \\
\hline \multicolumn{3}{|c|}{ Faktor Perilaku Orang Tua } \\
\hline $\begin{array}{l}\text { Tipe pekerjaan } \\
\text { Ayah/Ibu (X19\&X20) }\end{array}$ & $\begin{array}{l}\text { Pekerjaan dengan jam kerja } \\
\text { tertentu atau bebas }\end{array}$ & $\begin{array}{l}1=\text { pekerjaan terikat waktu } \\
0=\text { pekerjaan fleksibel waktu }\end{array}$ \\
\hline $\begin{array}{l}\text { Waktu kerja berangkat } \\
(\mathrm{X} 21)\end{array}$ & $\begin{array}{l}\text { Waktu berangkat sekolah sama } \\
\text { dengan berangkat kerja }\end{array}$ & $\begin{array}{l}1=\text { Ya } \\
0=\text { Tidak }\end{array}$ \\
\hline Waktu pulang (X22) & $\begin{array}{l}\text { Waktu pulang/istirahat kerja } \\
\text { bersamaan pulang sekolah }\end{array}$ & $\begin{array}{l}1=\text { Ya } \\
0=\text { Tidak }\end{array}$ \\
\hline Izin orang tua $(\mathrm{X} 23)$ & $\begin{array}{l}\text { Skala Likert izin orang tua anak } \\
\text { untuk bebas bepergian secara } \\
\text { mandiri ke sekolah, beraktivitas } \\
\text { di sekitar lingkungan rumah dan } \\
\text { ke luar kota }\end{array}$ & $\begin{array}{l}\text { 1-5: makin besar, responden semakin mandiri } \\
\text { dalam bepergian }\end{array}$ \\
\hline
\end{tabular}

Analisis korelasi antara variabel bebas dan variabel terikat dilakukan dengan menggunakan uji Chi-Square. Hanya variabel-variabel yang memiliki korelasi signifikan saja yang selanjutnya digunakan dalam uji pengaruh. Model Regresi Logistik Biner digunakan untuk mengetahui variabel yang berpengaruh signifikan.

\section{HASIL DAN PEMBAHASAN}

\section{Perbandingan Perjalanan Mandiri Anak}

Perjalanan mandiri anak tidak terlepas dari moda transportasi yang digunakan. Moda transportasi terbanyak yang digunakan adalah sepeda motor, yaitu hingga lebih dari $60 \%$ 
untuk berangkat. Meskipun penjemputan dengan sepeda motor berkurang, namun penggunaan transportasi berbasis aplikasi online meningkat untuk pulang sekolah.

Penggunaan kendaraan umum atau bus oleh siswa relatif rendah, dan bahkan tidak ada responden setelah penerapan sistem zonasi yang memilih untuk menggunakan angkutan umum atau bus untuk berangkat sekolah. Perjalanan secara aktif berupa berjalan kaki meningkat $5,4 \%$ saat berangkat dan meningkat $11,5 \%$ saat pulang. Selain itu, bersepeda juga meningkat $0,96 \%$.

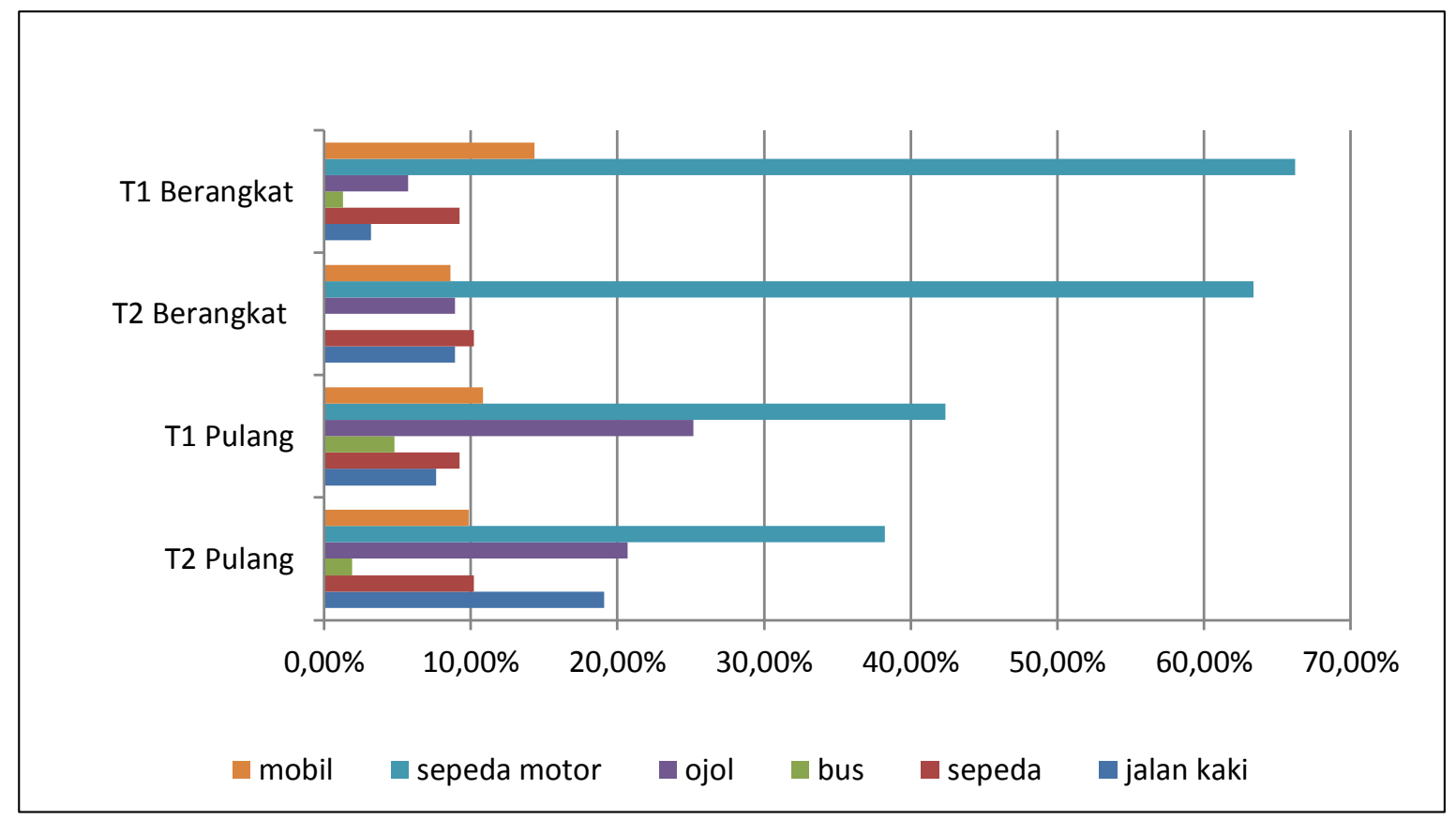

Gambar 1 Moda Transportasi Anak Berangkat dan Pulang Sekolah

Ditinjau dari arah perjalanan, perjalanan mandiri anak meningkat pada perjalanan berangkat sebesar $8,6 \%$ dan pada perjalanan pulang meningkat sebesar 5,1\%. Tipe 1, yaitu diantar-jemput, masih mendominasi pada kedua kelompok, yang artinya kurang lebih setengah siswa SMP sepenuhnya belum mandiri. Tipe 2, yaitu berangkat diantar-pulang mandiri, memiliki jumlah yang hampir sama dengan Tipe 4 , yaitu berangkat-pulang mandiri. Tipe 3, yaitu berangkat mandiri-pulang dijemput, paling sedikit atau kurang dari $1 \%$. Secara umum, keseluruhan tipe menunjukkan perbaikan, jika dibandingkan hasil penelitian siswa SMP di Kota Yogyakarta pada tahun 2011 (Hidayati, 2011). Hal ini menunjukkan bahwa suatu kebijakan memang dapat memberikan dampak yang lebih cepat, meskipun dampak ini bukan merupakan tujuan utama kebijakan tersebut.

Sebaran lokasi rumah responden dan rute terpendek ditunjukkan pada Gambar 3. Informasi ini selanjutnya digunakan untuk melakukan analisis data. 
Perbandingan Berangkat dan

Pulang Sekolah

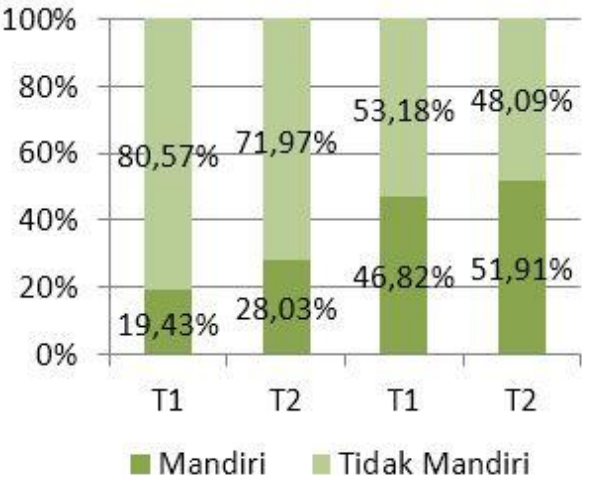

Perbandingan Tipe Mobilitas Mandiri

Siswa SMP

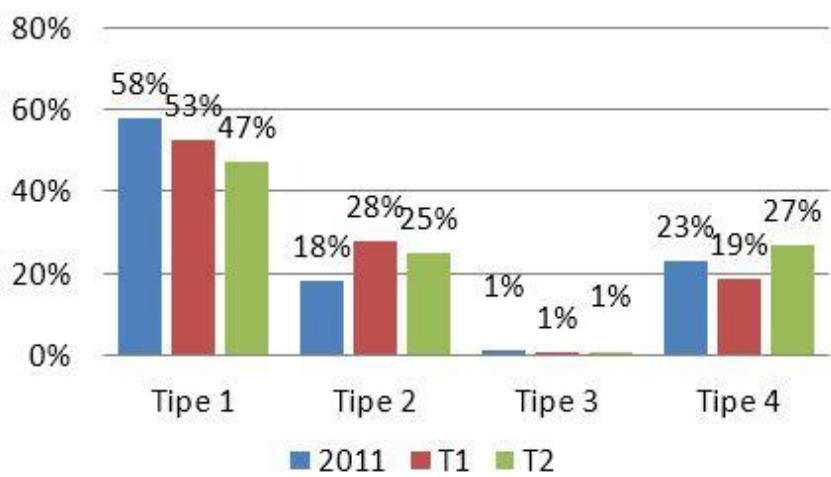

Gambar 2 Perbandingan Perjalanan Mandiri Anak
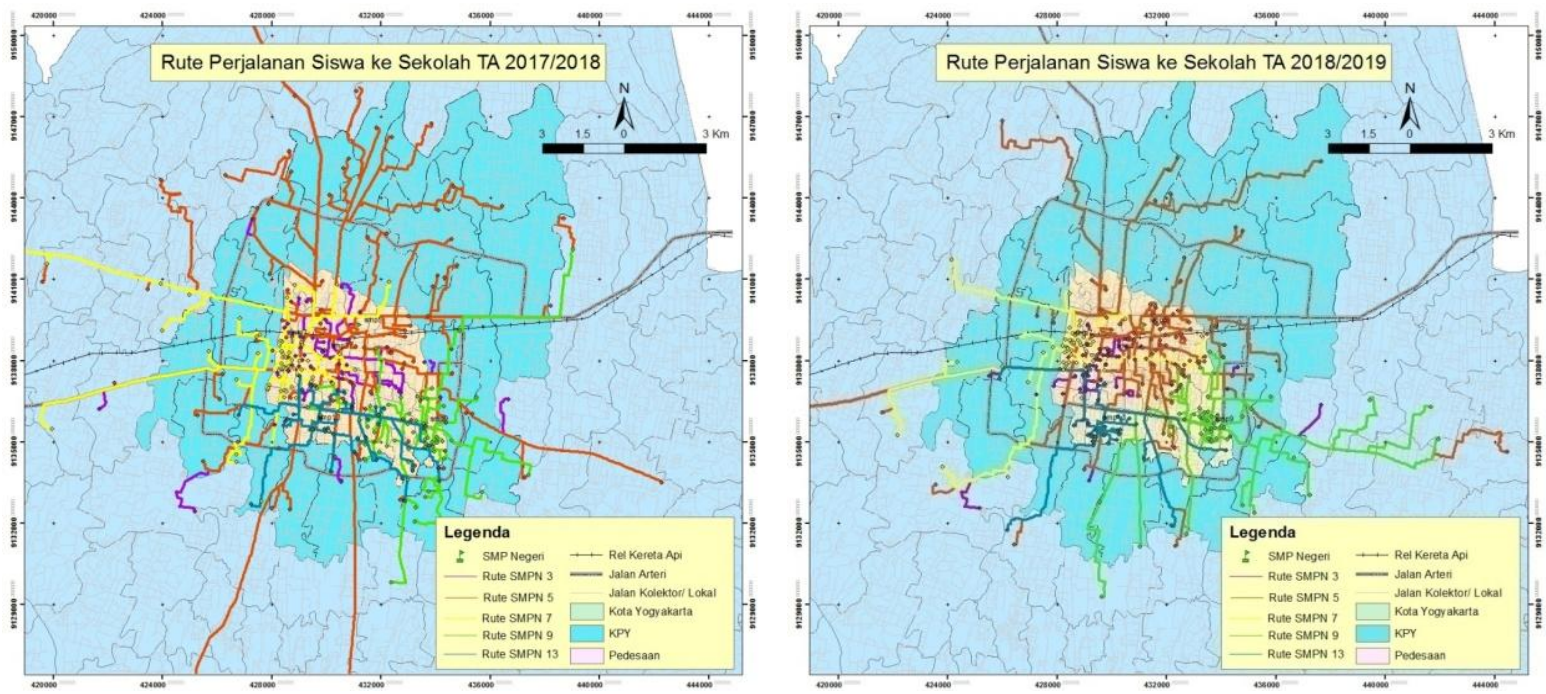

Gambar 3 Sebaran Lokasi Rumah dan Rute Terpendek

\section{Analisis Korelasi Variabel}

Hasil uji chi-square menunjukkan bahwa kurang dari separuh faktor memiliki korelasi yang signifikan, dengan $\alpha$ lebih kecil daripada 0,05 , terhadap mobiltas mandiri anak. Lebih sedikit variabel yang berkorelasi sebelum penerapan sistem zonasi sekolah daripada variebel yang berkorelasi setelah penerapan sistem zonasi sekolah.

\section{Perjalanan Mandiri Anak Berangkat Sekolah}

Hasil model regresi logistik biner untuk perjalanan mandiri anak berangkat sekolah disajikan pada Tabel 5. Nilai koefisien yang postif memiliki arti bahwa variabel bebas merupakan pendorong anak untuk melakukan perjalanan mandiri. Sebaliknya koefisien yang bernilai negatif berarti bahwa variabel menjadi penghambat. Besarnya pengaruh ditunjukkan pada nilai proporsi, sedangkan huruf tercetak tebal merupakan variabel yang signifikan pada $\alpha$ lebih kecil daripada 0,05 . 
Tabel 4 Nilai Rata-rata Data Responden dan Hasil Uji Chi-Square Antarvariabel

\begin{tabular}{|c|c|c|c|c|c|c|c|c|c|c|c|}
\hline \multirow[b]{3}{*}{ Faktor } & \multirow[b]{3}{*}{ Var. } & \multicolumn{5}{|c|}{2017} & \multicolumn{5}{|c|}{2018} \\
\hline & & \multirow{2}{*}{$\begin{array}{l}\text { Rata- } \\
\text { rata* }\end{array}$} & \multicolumn{2}{|c|}{ Berangkat } & \multicolumn{2}{|c|}{ Pulang } & \multirow{2}{*}{$\begin{array}{l}\text { Rata- } \\
\text { Rata* }\end{array}$} & \multicolumn{2}{|c|}{ Berangkat } & \multicolumn{2}{|c|}{ Pulang } \\
\hline & & & $x^{2}$ & df & $\mathrm{x}^{2}$ & $\mathrm{df}$ & & $x^{2}$ & $\mathrm{df}$ & $x^{2}$ & $\mathrm{df}$ \\
\hline Pola & $\mathrm{X} 1$ & $2.938 \mathrm{~m}$ & 22.358 & 5 & 11.89 & 5 & 3,041 & 34.928 & 5 & 34.066 & 5 \\
\hline \multirow[t]{2}{*}{ Perjalanan } & $\mathrm{X} 2$ & $14 \mathrm{mnt}$ & 4.774 & 2 & 7.471 & 2 & $11 \mathrm{mnt}$ & 10.593 & 2 & 9.772 & 2 \\
\hline & $\mathrm{X} 3$ & 1 (rmh) & - & - & 0.142 & 1 & 1 (rmh) & - & - & 8.143 & 1 \\
\hline Bentuk & $\mathrm{X} 4$ & 3 (kota) & 3.780 & 2 & 3.932 & 2 & 3 (kota) & 10.174 & 2 & 4.036 & 2 \\
\hline \multirow[t]{4}{*}{ Kota } & $\mathrm{X} 5$ & 1 & 9.630 & 1 & 3.416 & 1 & 1 & 9.997 & 1 & 6.824 & 1 \\
\hline & X6 & 0 & 0.013 & 1 & 0.823 & 1 & 0 & 0.041 & 1 & 1.255 & 1 \\
\hline & $\mathrm{X} 7$ & 1,35 & 2.012 & 1 & 0.208 & 1 & 1,62 & 1.506 & 1 & 6.390 & 1 \\
\hline & $\mathrm{X} 8$ & 1 & 0.822 & 1 & 0.372 & 1 & 1 & 4.617 & 1 & 5.864 & 1 \\
\hline Sosio- & X9 & $0(\mathrm{pr})$ & 15.688 & 1 & 12.371 & 1 & $0(\mathrm{pr})$ & 5.587 & 1 & 8.760 & 1 \\
\hline \multirow[t]{5}{*}{ ekonomi } & $\mathrm{X} 10$ & 2 (anak) & 0.515 & 2 & 4.129 & 2 & 2 (anak) & 0.896 & 2 & 0.624 & 2 \\
\hline & $\mathrm{X} 11$ & 5,5 (juta) & 6.105 & 3 & 2.354 & 3 & 4,8 (juta) & 8.277 & 3 & 1.632 & 3 \\
\hline & $\mathrm{X} 12$ & 1 (buah) & 1.945 & 1 & 0.336 & 1 & 1 (buah) & 10.757 & 1 & 11.300 & 1 \\
\hline & X13 & 2 (buah) & 1.932 & 1 & 0.325 & 1 & 2 (buah) & 0.209 & 1 & 0.010 & 1 \\
\hline & X14 & 2 (buah) & 1.347 & 1 & 0.106 & 1 & 2 (buah) & 1.724 & 1 & 0.005 & 1 \\
\hline Persepsi & $\mathrm{X} 15$ & 2,99 & 2.226 & 2 & 0.362 & 2 & 3,04 & 4.482 & 2 & 2.322 & 2 \\
\hline \multirow[t]{3}{*}{ Anak } & $\mathrm{X} 16$ & 2,50 & 1.196 & 2 & 1.346 & 2 & 2,59 & 2.206 & 2 & 2.571 & 2 \\
\hline & $\mathrm{X} 17$ & 3,44 & 0.686 & 2 & 7.149 & 2 & 3,51 & 4.710 & 2 & 5.685 & 2 \\
\hline & $\mathrm{X} 18$ & 3,20 & 11.553 & 2 & 5.025 & 2 & 3,26 & 11.617 & 2 & 7.909 & 2 \\
\hline Perilaku & X19 & 1 & 1.197 & 1 & 0.858 & 1 & 1 & 1.305 & 1 & 0.497 & 1 \\
\hline \multirow[t]{4}{*}{ Orang Tua } & X20 & 0 & 0.354 & 1 & 0.337 & 1 & 0 & 0.405 & 1 & 0.435 & 1 \\
\hline & $\mathrm{X} 21$ & 0 & 1.259 & 1 & - & - & 0 & 1.920 & 1 & - & - \\
\hline & $\mathrm{X} 22$ & 0 & - & - & 9.845 & 1 & 0 & - & - & 7.490 & 1 \\
\hline & $\mathrm{X} 23$ & 3,27 & 9.144 & 2 & 19.984 & 2 & 3,1 & 16.03 & 2 & 12.455 & 2 \\
\hline
\end{tabular}

* Rata-rata nilai hasil isian kuisioner responden

** Angka tercetak tebal, signifikan pada $\alpha<0,05$

Tabel 5 Model Regresi Logistik Biner Perjalanan Mandiri Anak Berangkat Sekolah

\begin{tabular}{|c|c|c|c|c|}
\hline \multirow[t]{2}{*}{ Variabel } & \multicolumn{2}{|c|}{2017} & \multicolumn{2}{|c|}{2018} \\
\hline & Coef. & Proporsi & Coef. & Proporsi \\
\hline Jarak rumah & $-0,206$ & 0,814 & $-0,540$ & 0,583 \\
\hline Lama waktu & & & 0,059 & 1,061 \\
\hline Lokasi rumah & & & $-0,370$ & 0,691 \\
\hline Penyebrangan arteri atau rel & $-0,463$ & 0,629 & $-0,101$ & 0,904 \\
\hline Jenis kelamin & 0,839 & 2,315 & 0,297 & 1,346 \\
\hline Pendapatan orang tua & & & $-0,066$ & 0,936 \\
\hline Kepemilikan mobil & & & $-0,510$ & 0,600 \\
\hline Dukungan teman & 0,466 & 1,594 & 0,287 & 1,333 \\
\hline Izin orang tua & 0,491 & 1,634 & 0,691 & 1,996 \\
\hline Constant & $-3,193$ & 0,041 & $-0,617$ & 0,540 \\
\hline Pseudo & 0,165 & & 0,219 & \\
\hline
\end{tabular}

Terdapat 5 variabel yang sama-sama berpengaruh pada kedua kelompok. Dua variabel berupa kondisi fisik pola perjalanan dan bentuk kota. Jarak tempat tinggal semakin jauh, menjadi hambatan signifikan terhadap perjalanan mandiri anak. Berdasarkan tabel variasi jarak penggunaan moda tranportasi, terlihat bahwa semakin jauh jarak, semakin terbatas pilihan moda. Penelitian ini mendukung penelitan-penelitan sebelumnya (Hidayati, 2011; Nugraha dan Dewi, 2018; Putri et al., 2019). 
Secara umum rute yang menyeberangi jalan arteri atau rel kereta api, menghambat perjalanan mandiri siswa. Tidak hanya pada siswa SD (Putri et al., 2019; Mitra dan Buliung, 2015), penelitian ini juga menunjukkan pengaruh tersebut pada siswa SMP.

Tiga variabel lain adalah jenis kelamin, dukungan teman, dan izin orang tua. Pandangan umum bahwa anak laki-laki lebih mandiri daripada anak perempuan terbukti berpengaruh signifikan. Hal ini menguatkan rangkuman McMillan (2005) dari penelitianpenelitan yang dilakukan di berbagai tempat. Anak-anak yang mendapat dukungan teman, mendorong anak mendapat hasil yang sama untuk melakukan perjalanan bersama-sama (Carver et al., 2014; Race et al., 2017). Sedangkan izin orang tua merupakan variabel yang signifikan berpengaruh pada kedua kelompok. Hal ini menunjukkan bahwa pengaruh orang tua sangat kuat dalam perjalanan mandiri anak. Hasil ini mendekati kerangka konsep McMillan (2005), yang menjadikan orang tua sebagai penentu dalam mengambil keputusan.

Terdapat 4 variabel yang hanya berpengaruh pada siswa setelah pemberlakuan sistem zonasi penerimaan siswa baru. Durasi lama waktu perjalanan justru menjadi faktor pendorong pada moblitas mandiri anak. Hal ini memiliki arti bahwa anak yang memiliki waktu yang cukup atau tidak terburu-buru berangkat ke sekolah, lebih berpeluang melakukan perjalanan mandiri.

Lokasi rumah di perkotaan menghambat anak melakukan perjalanan mandiri. Hasil ini berbeda dengan hasil penelitian Carver et al. (2014), yang menyatakan bahwa siswa-siswa di perkotaan lebih mandiri.

Semakin tinggi pendapatan orang tua, semakin tinggi kecenderungan anak untuk diantar. Pendapatan orang tua ini mungkin berkaitan dengan kepemilikan kendaraan. Pada penelitian ini angka kepemilikan sepeda motor mencapai 98\%, sehingga kecenderungan diantar bergerser pada keluarga yang memiliki mobil. Meskipun jumlah anak bersekolah dalam keluarga tidak berpengaruh, alasan kepraktisan untuk berangkat bersama dengan kakak, adik, dan orang tua bekerja mendukung penelitian-penelitian sebelumnya (McMillan, 2005; Mitra dan Buliung, 2015).

\section{Perjalanan Mandiri Anak Pulang Sekolah}

Model regresi logistik biner siswa sebelum penerapan sistem zonasi menggunakan 6 variabel, sedangkan model setelah penerapan sistem zonasi sekolah menggunakan 11 variabel. Hasil model regresi pada perjalanan pulang sekolah ditunjukkan pada Tabel 6.

Variabel-variabel yang berpengaruh pada perjalanan pulang hampir sama dengan variabel-variabel yang berpengaruh pada perjalanan berangkat. Jarak, jenis kelamin, dan izin orang tua memiliki kesamaan pengaruh, sedangkan durasi lama waktu perjalanan memiliki perbedaan pengaruh. Pada perjalanan pulang siswa yang membutuhkan waktu lama cenderung melakukan perjalanan secara tidak mandiri.

Selain izin orang tua, waktu orang tua pulang atau istirahat kerja bersamaan dengan waktu pulang sekola,h memilik pengaruh yang signifikan. Hasil ini sedikit berbeda dengan Mitra dan Buliung (2015), yang mendapati bahwa waktu berangkat kerja bersamaan, pada penelitian ini waktu pulang atau waktu istirahat, yang berpengaruh signifikan menghambat 
anak berjalan mandiri. Hal ini semakin menguatkan konsep McMillan (2005) bahwa orang tua berperan besar dalam mengambil keputusan.

Tabel 6 Model Regresi Logistik Biner Perjalanan Mandiri Anak Pulang Sekolah

\begin{tabular}{lcccc}
\hline \multirow{2}{*}{ Variabel } & \multicolumn{2}{c}{2017} & \multicolumn{2}{c}{2018} \\
\cline { 2 - 5 } & $\begin{array}{c}\text { Coef. } \\
\text { B }\end{array}$ & $\begin{array}{c}\text { Proporsi } \\
\text { Exp(B) }\end{array}$ & $\begin{array}{c}\text { Coef. } \\
\text { B }\end{array}$ & $\begin{array}{c}\text { Proporsi } \\
\text { Exp(B) }\end{array}$ \\
\hline Jarak rumah & -0.074 & 0.929 & -0.197 & 0.821 \\
Lama waktu & -0.311 & 0.732 & -0.110 & 0.896 \\
Tujuan pulang & & & $\mathbf{- 1 . 3 0 9}$ & $\mathbf{0 . 2 7 0}$ \\
Penyebrangan & & & -0.124 & 0.883 \\
Rute langsung & & & $\mathbf{- 0 . 7 4 1}$ & $\mathbf{0 . 4 7 6}$ \\
Akses kendaraan umum & & & 0.167 & 1.182 \\
Jenis kelamin & $\mathbf{0 . 5 8 2}$ & $\mathbf{1 . 7 9 0}$ & 0.510 & 1.665 \\
Kepemilikan mobil & & & -0.513 & 0.599 \\
Keamanan lingkungan & 0.059 & 1.060 & & \\
Dukungan teman & & & 0.241 & 1.273 \\
Waktu orang tua pulang & $\mathbf{0 . 6 9 9}$ & $\mathbf{0 . 4 9 7}$ & $\mathbf{- 0 . 8 1 7}$ & $\mathbf{0 . 4 4 2}$ \\
Izin orang tua & $\mathbf{0 . 6 3 8}$ & $\mathbf{1 . 8 9 2}$ & $\mathbf{0 . 5 2 0}$ & $\mathbf{1 . 6 8 2}$ \\
Constant & -1.013 & 0.363 & 1.572 & 4.816 \\
\hline & 0.157 & & 0.146 &
\end{tabular}

Hanya 1 variabel yang berpengaruh pada siswa sebelum penerapan sistem zonasi, yaitu pandangan terhadap keamanan lingkungan. Pada penelitian Race et al., (2017), keamanan lingkungan ditinjau dari ketakutan anak terhadap orang asing atau tindak kejatahan. Pada penelitian ini, ternyata hal tersebut terbukti berpengaruh, meskipun hanya muncul sekali dan tidak signifikan.

Setelah penerapan zonasi, ternyata lebih banyak variabel yang berpengaruh. Dua variabel yang berpengaruh signifikan adalah tujuan pulang dan rute langsung. Tujuan pulang yang langsung ke rumah membuat anak tidak mandiri. Dengan tidak dibatasi waktu, anak dapat melakukan kegiatan tambahan sepulang sekolah dan pilihan moda transportasi semakin beragam bagi siswa yang tidak langsung pulang (Schlosberg, 2006). Keinginan untuk cepat sampai rumah sering diungkapkan dalam alasan siswa dijemput dengan menggunakan sepeda motor. Jika rute yang dilalui semakin jauh atau melambung dari jarak lurus, kecenderungan anak dijemput semakin kuat. Keberadaan jaringan jalan yang semakin banyak memunginkan rute perjalanan yang pendek mendekati jarak lurus (Schlossber et al., 2006). Rute yang pendek ini mendorong anak untuk berjalan kaki atau bersepeda (Mitra dan Buliung, 2015). Pada penelitian ini, ditunjukkan bahwa anak yang pulang berjalan kaki naik sebesar 10,2\% dibandingkan dengan anak yang berangkat sekolah.

Empat variabel lain memiliki pengaruh namun tidak signifikan. Penyeberangan jalan arteri atau rel kereta api, kepemilikan mobil, dan dukungan teman memiliki kesamaan pengaruh dengan perjalanan berangkat sekolah. Lokasi tempat tinggal dalam jarak 400 meter dari halte atau trayek kendaraan umum memudahkan akses siswa untuk menggunakan kendaraan umum (Mitra dan Buliung, 2015). Hasil penelitian ini menunjukkan keterkait- 
annya dengan perjalanan mandiri anak pulang sekolah, namun ternyata pilihan kendaraan umum bukan pilihan utama. Hal ini ditunjukan dalam jumlah siswa pulang dengan kendaraan umum, yang hanya sebesar $2 \%$.

\section{Kerangka Konsep Perjalanan Mandiri Anak pada Perjalanan ke Sekolah}

Sebagian faktor pendorong dan penghambat perjalanan mandiri anak memiliki kesamaan, baik perjalanan berangkat maupun perjalanan pulang sekolah. Faktor-faktor yang muncul pada kedua kelompok dapat digunakan sebagai faktor yang secara umum berpengaruh pada siswa SMP. Taraf signifikan 95\%, mempersempit jumlah faktor yang diukur, sehingga dapat mengerucut pada suatu fator yang paling berpengaruh.

Tabel 7 Variasi Jarak Penggunaan Moda Tranportasi Respoden

\begin{tabular}{|c|c|c|c|c|c|c|c|}
\hline \multirow{2}{*}{ Moda } & \multirow{2}{*}{ Arah } & \multirow{2}{*}{ Terdekat } & \multicolumn{2}{|c|}{ Rata-Rata } & \multirow{2}{*}{ Terjauh } & \multicolumn{2}{|c|}{ Batasan } \\
\hline & & & 2017 & 2018 & & Dekat & Jauh \\
\hline \multirow[t]{2}{*}{ Jalan kaki } & Berangkat & 41 & 342 & 434 & 1.902 & 0 & 2.000 \\
\hline & Pulang & 41 & 832 & 1.336 & 2.320 & 0 & 2.500 \\
\hline Sepeda & P-P & 135 & 1.124 & 1.356 & 6.664 & 0 & 7.000 \\
\hline \multirow[t]{2}{*}{ Bus } & Berangkat & 5.030 & 6.458 & - & 7.107 & 5.000 & 7.000 \\
\hline & Pulang & 452 & 4.299 & 5.304 & 7.788 & 500 & 8.000 \\
\hline \multirow[t]{2}{*}{ Ojek online } & Berangkat & 473 & 3.669 & 3.304 & 11.680 & 500 & 12.000 \\
\hline & Pulang & 440 & 3.172 & 4.403 & 19.249 & 500 & 20.000 \\
\hline
\end{tabular}

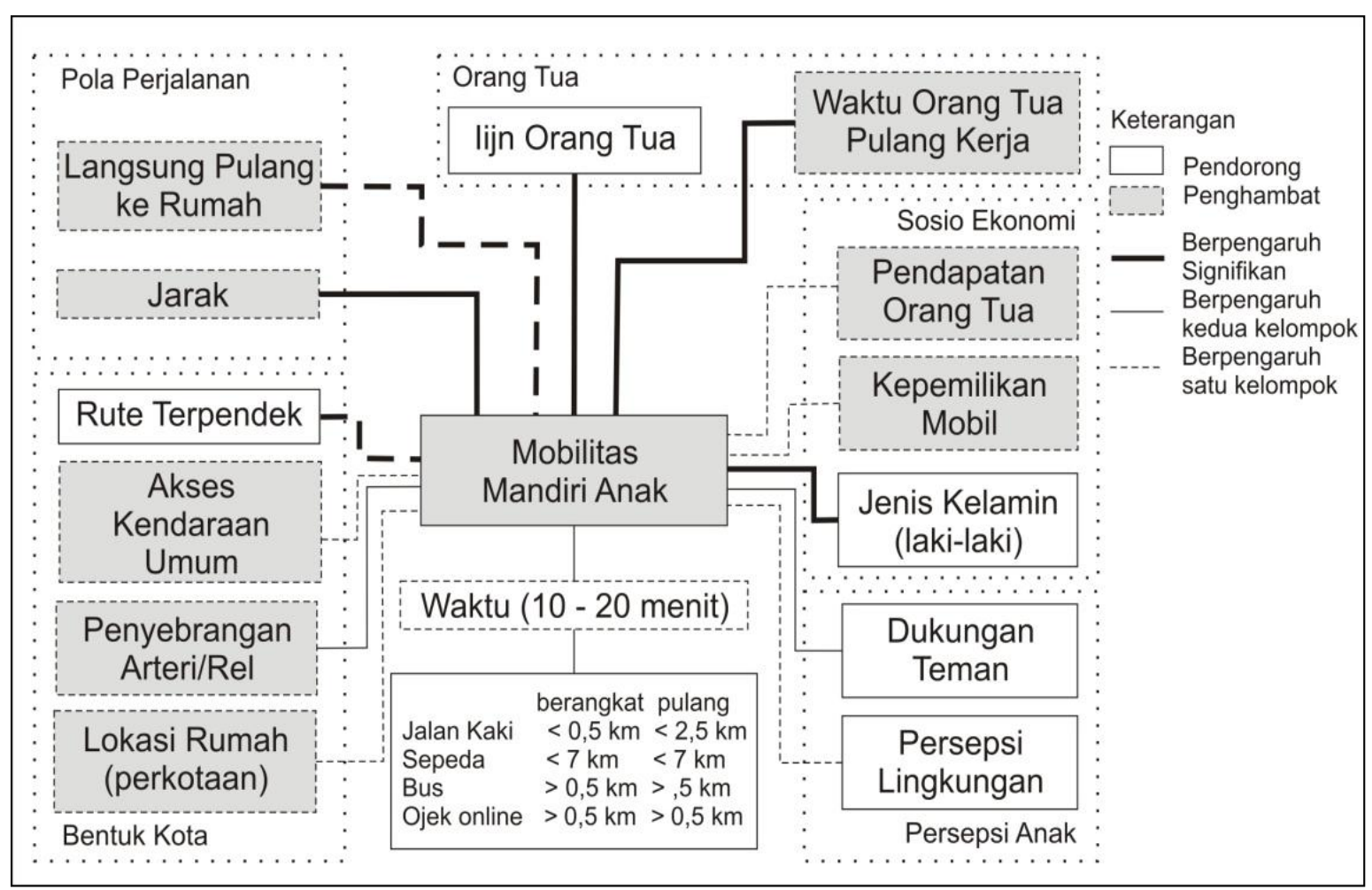

Gambar 4 Kerangka Konsep Perjalanan Mandiri Anak pada Perjalanan ke Sekolah 
Pada tahap akhir, jarak dan durasi perjalanan menjadi batas pilihan moda yang mungkin digunakan. Dari data yang diperoleh, jarak terjauh dan jarak terdekat digunakan sebagai batas atas dan batas bawah masing-masing moda. Sedangkan durasi dapat menjadi hambatan maupun menjadi dorongan Sebagai contoh, pilihan anak untuk mau melakukan perjalanan lebih lama adalah dengan menggunakan bus. Mengacu pada pembagian rentang durasi perjalanan yang digunakan pada penelitian ini, durasi yang disarankan adalah antara 10 menit hingga 20 menit.

Rangkuman hasil penelitian ini disusun dalam kerangka konsep perjalanan mandiri anak. Kerangka konsep tersebut menggambarkan bagaimana keputusan perjalanan berangkat dan pulang sekolah pada siswa SMP diambil, seperti yang terdapat pada Gambar 4.

\section{KESIMPULAN}

Di Kota Yogyakarta, perjalanan mandiri anak ke sekolah siswa SMP setelah penerapan sistem zonasi sekolah lebih tinggi daripada perjalanan mandiri siswa SMP sebelum penerapan sistem zonasi sekolah. Namun tipe perjalanannya masih relatif sama. Siswa yang diantar-jemput masih mendominasi hingga $47 \%$.

Terdapat persamaan dan perbedaan faktor yang memengaruhi perjalanan siswa di antara kedua kelompok. Variabel yang selalu muncul signifikan adalah izin orang tua sebagai pendorong, sedangkan waktu orang tua pulang atau istirahat kerja bersamaan pulang sekolah signifikan menghambat peluang anak pulang sendiri.

Anak laki-laki secara umum lebih mandiri daripada anak perempuan dan jarak rumah membatasi pilihan moda transportasi yang mungkin digunakan. Selain itu, perjalanan bersama teman menjadi peluang untuk mendorong anak lebih mandiri. Tujuan pulang langsung ke rumah cenderung membuat anak dijemput orang tua. Sedangkan rute yang semakin dekat memungkinkan anak berjalan kaki atau bersepeda.

Hasil penelitian ini menunjukkan bahwa masih besar pengaruh orang tua pada perjalanan mandiri siswa SMP. Pada jarak jauh, angkutan umum masih kurang diminati siswa SMP. Moda transportasi berbasis aplikasi semakin diminati siswa SMP, karena dinilai praktis dan terjangkau. Sayangnya, moda ini dapat meningkatkan penggunaan kendaraan bermotor, menimbulkan kemacetan lalu lintas, meningkatkan konsumsi BBM, dan menimbulkan polusi udara. Hal ini menjadi tantangan pada perencanaan transportasi, terutama yang dimaksudkan bagi siswa sekolah di masa depan.

\section{DAFTAR PUSTAKA}

Ahern, S.M., Arnott, B., Chatterton, T., de Nazelle, A., Kellar, I., dan McEachan, R.R.C. 2017. Understanding Parents' School Travel Choices: A Qualitative Study Using The Theo-retical Domains Framework. Journal of Transport \& Health, 4: 278-293. 
Akbar, R. Z. 2019. Pola Perjalanan Pelajar Tanpa Sistem Zonasi dan dengan Sistem Zonasi: Studi Kasus: SMA Negeri 1 Yogyakarta. Tesis tidak diterbitkan. Yogyakarta: Universitas Gadjah Mada.

Aprilia, R.N. 2014. Perilaku Perjalanan Sekolah Pelajar Sekolah Menengah Pertama di Kelurahan Panggungharjo, Kecamatan Sewon, Kabupaten Bantul. Skripsi tidak diterbitkan. Yogyakarta: Universitas Gadjah Mada.

Badan Standardisasi Nasional (BSN). 2004. Tata Cara Perencanaan Lingkungan Perumahan di Perkotaan. SNI No. 03-1733-2004. Jakarta.

Buliung, R.N., Larsen, K., Faulkner, G., dan Ross, T. 2017. Children's Independent Mobility in the City of Toronto, Canada. Travel Behaviour and Society, 9: 58-69.

Carver, A., Panter, J.R., Jones, A.P., dan van Sluijs, E.M.F. 2014. Independent Mobility on The Journey to School: A Joint Cross-Sectional and Prospective Exploration of Social and Physical Environmental Influences. Journal of Transport \& Health, 1: 25-32.

Hidayati, I. 2011. Pola Mobilitas Rumah-Sekolah pada Anak-Anak di Yogyakarta. Laporan Penelitian Lab. Perencanaan Wilayah dan Kota tidak diterbitkan. Yogyakarta: Universitas Gadjah Mada.

Marzi, I. dan Reimers, A. K. 2018. Children's Independent Mobility:Current Knowledge, Future Directions, and Public Health Implications. International Journal Enviromental Research and Public Health, 15 (11): 2441.

McMillan, T.E. 2005. Urban Form and a Child's Trip toSchool: The Current Literature anda Framework for Future Research. Journal of Planning Literature, 19 (4): 440456.

Mitra, R. dan Buliung, R.N. 2015. Exploring Differences in School Travel Mode Choice Behaviour between Children and Youth. Transport Policy, 42: 4-11.

Nugraha, E. dan Dewi, D.I.K. 2018 Pola Perjalanan Siswa Sekolah Dasar di Kecamatan Semarang Tengah. Teknik PWK (Perencanaan Wilayah Kota), 7 (3): 190-199.

Putri, D.W., Widyawati, dan Susiloningtyas, D. 2019. Spatial Behavior of Children's Independent Mobility in Depok, West Java, Indonesia. IOP Conference Series: Earth and Environmental Science, 338, 012009.

Race, D.L., Sims-Gould, J., Lee, N.C., Frazer, A.D., Voss, C., Naylor P.J., dan McKay, H.A. 2017. Urban and Suburban Children's Experiences with School Travel-A Case Study. Journal of Transport \& Health, 4: 305-315.

Schlossber, M., Greene, J., Phillips., P.P., Johnson, B., dan Parker, B. 2006. Effects of Urban Form and Distances on Travel Mode. Journal of the American Planning Association, 72 (3): 337-346.

Setiawan, Y. 2011. Travel Behavior of Junior High School Children in Sleman Urban Area, Yogyakarta Special Province-Indonesia. Tesis tidak diterbitkan. Yogyakarta: Universitas Gadjah Mada. 
Van Geoverden, C.D. dan de Boer, E. 2013. School Travel Behaviour in The Netherlands and Flan-ders. Transport Policy, 26 (1): 73-84. 